\title{
APPLICATION OF EXERGY ANALYSIS FOR ESTIMATION OF GEOTECHNICAL SYSTEMS STABILITY
}

\author{
Mikhail V. Romanov \\ Andrey V. Shamshin and Oleg G. Vorobyev \\ St. Petersburg State Technical University, Russia
}

The opportunity of application of exergy analysis for estimation of geotechnical systems is considered.

The example of use of the exergy method for estimation of pollution of water-producing area of the small rivers is given.

Using concept of exergy we have the necessary information about technical object and environment and are able to define current condition and variants of the territory development.

KEYWORDS: exergy; exergy method of thermodynamic analysis; geotechnical systems; ecological danger of chemical substances, environmental load.

An objective criteria for assessment of influence of technogenic load on environment offers exergy. Exergy, also known as availability, is a measure of the maximum useful work that can be obtained when a system is brought to a state of equilibrium with the environment in reversible processes [1]. Due to the irreversibility of real processes, the work obtained is always less than the maximum work. Hence, by analyzing work loss within a system, imperfiections can be pinpointed and quantified, and possible improvements suggested.

It is exergy method of the thermodynamic analysis that allow to estimate both energy conversation processes and damage to the environment. Also, diffierent sorts of energy can be directly compared in exergetic terms. One can also use the Grassmann diagrams, on which the width of a flow line is determined by its exergy value, are used to illustrate the exergy flow across a system.

Exergy method can be applied for the analysis of thermal, chemical and metallurgical plants, technological chains of processes, the life cycle of a product or a whole country. Combined with ecological and economic theories, exergy can be used for ecology-economic optimization in a system. 
We propose to use the exergy method of the thermodynamic analysis for estimation of ecological danger of chemical substances.

Now sanitaro-hygienic specifications of allowable contents of harmful substances are maximum permissible concentrations of polluting substances. They are called to ensure health and safety of the man in industrial and household conditions and normal life of ecosystem. Normalization of allowable contents of chemical substances in an environment is based on representation about presence of threshold action. We believe, that use of chemical exergy will be able to add current methods of estimation.

Exegy concept uses in ecology recently. It is necessary to mention the works of G. Wall [2] and M. Gong [3], V. S. Stepanov [4], G. T. Frumin [5] and so on. Analyzing their and other works, one can allocate two directions in which the researches are developed:

1) application of exergy analysis for a complex estimation of technogenic load for environment [6-8];

2) use of chemical exergy for definition of potential danger of various polluting substances [5].

We consider two directions in detail.

The active economic activity of the man has resulted in formation of original hybrid complexes consisting of technical objects and ecological systems. We shall name such complexes by geotechnical systems (GTS). There are the special laws of functioning in the GTS. First of all, it is transformation of natural circulation of matter and energy [7, 9].

According to the second law of thermodynamics energy in system, including in the GTS, is lost in such form, which cannot be used again without work. It is this part of energy, that pollute environment. There is degradation of energy to forms, which are difficult for use, in open systems, including the GTS. Environmental pollution is defined both energy and mass degradations $[10,11]$.

The general diagram of the GTS is submitted in fig. 1. The interaction between technical object and environment occurs in exchange of substance, energy and information. Thus the stability of the GTS is provided in some range of allowable changes of intensity of technogenic influences. Definition of this range is rather complex question, and these influences are very various.

Exergy analysis allows to estimate any kinds of waste processes (material and power components) in terms of energy. It gives an opportunity to compare ecological condition of the GTS to various modular structure of waste and to carry out ecological normalization of technogenic load and regulation by economic activity.

The second direction of use of chemical exergy is definition of potential danger of various polluting substances. According to the data of statistics it is known more than 10 millions of chemical substances and number of new chemical substances is approximately 500 ones per year [5]. Toxicity and danger of various chemical substances traditionally are defined on the basis of 
their sanitary-hygienic parameters - maximum permissible concentration (MPC). An experimental substantiation of the MPC for practically any of chemical substances is rather expensive and long process (1,5 - 2 years) [12].

Schema of interaction between chemical structure and biological activity of substances

Fig. 2

So the application of express methods for definition of chemical substances toxicity, danger and the MPC is very perspective on the base of various physico-chemical constants. In 1956 the Russian scientist N. Lazarev has presented chart showing that structure, chemical activity and the physico-chemical constants of substances mutually cause their properties and biological activity [12] (fig. 2).

Such physico-chemical constants of substances as molecular weight, points of boiling and melting, parameters of solubility and others is most frequently used for rough definition of values of toxicity and the MPC in industrial toxicology $[12,13]$.

Apparently, it is more perspective to consider estimation of chemical substances potential danger with help of their chemical exergy. For example, G. Frumin shows in work [5] on the basis of experiments with hydrobiontes (in particular, gold fish), that the larger value of chemical exergy of substance the larger danger of this substance for environment. In principle it follows from definition of exergy. However it is necessary to remember various mechanisms of chemical substances influence for environment. One group of substances acts instantly, others are capable to exist long time collecting in various components of environment and, thus, subsequently resulting to various infringements in function of ecosystem.

We have made an attempt to unit two above mentioned directions of exergy application. We consider some territory, for example, water-producing area of small river, which represents steady ecosystem with the usual circulation of matter and energy. There are three water-producing areas 
with various economic load. The value of discharge into the atmosphere in researched waterproducing areas is given in table 1 . We try to estimate an ecological condition and prospects of development of these territories according to the exergy concept.

Table 1

Total discharge into the air of water-producing areas (tons/year), data of 1994

\begin{tabular}{|c|c|c|c|c|c|c|}
\hline $\begin{array}{c}\text { Number of } \\
\text { water- } \\
\text { producing } \\
\text { area }\end{array}$ & $\begin{array}{c}\text { Water- } \\
\text { producing } \\
\text { area, } \mathrm{km}^{2}\end{array}$ & \multicolumn{5}{|c|}{ Polluting substances, ton/year } \\
\hline & & $\begin{array}{c}\text { Solid } \\
\text { substances }\end{array}$ & $\begin{array}{c}\text { Sulphureous } \\
\text { anhydride }\end{array}$ & $\begin{array}{c}\text { Oxides of } \\
\text { nitrogen }\end{array}$ & Hydrocarbons & $\begin{array}{c}\text { Oxid } \\
\text { carb }\end{array}$ \\
\hline 1. & 65 & 126 & 14 & 9,9 & 0,1 & 0,2 \\
\hline 2. & 123 & 13 & 304 & 2,5 & 8,8 & 1 \\
\hline 3. & 45 & 231 & 366 & 10,6 & 98 & 0,1 \\
\hline
\end{tabular}

We offer a criterion of chemical load normalization:

$$
\sum_{i=1}^{\alpha_{i} \cdot \mu_{i} \cdot e_{i}} \leq k_{\max }
$$

where $\alpha_{i}=\frac{e_{1}}{\mathrm{e}_{0}}$ - parameter of relative danger of substance $i$ for environment;

$e_{i}$ - value of chemical exergy of substance $i[\mathrm{~J} / \mathrm{mole}]$;

$e_{0}$ - value of chemical exergy of some conditional substance of comparison, accepted for the standard, for example, $\mathrm{SO}_{2},[\mathrm{~J} / \mathrm{mole}]$;

$\mu_{i}$ - quantity of substance $i$ [mole];

$f$ - correction factor, taking into account various speed of autopurification in different physicogeographical zones;

$S$ - water-producing area of the small river $\left[\mathrm{km}^{2}\right]$;

$k_{\text {max }}$ - maximum permissible chemical load [ $\mathrm{Jl} /\left(\mathrm{km}^{2} \cdot\right.$ year $\left.)\right]$.

We also take into account, that 


$$
\mathrm{e}_{\mathrm{i}}=\sum_{\mathrm{j}=1} \mu_{\mathrm{j}} \cdot \mathrm{e}_{\mathrm{j}}^{0}+\Delta \mathrm{G}_{\mathrm{i}}^{0}
$$

where $\mu_{j}$ - mole share of element $j$;

$e^{0}{ }_{j}$ - free enthalpy of devaluation of element $j$ (simple substance), included in structure of substance $i$

$\Delta \mathrm{G}^{0}{ }_{\mathrm{i}}$ - standard free energy of formation of substance $i$ (the Gibbs' energy) [4].

$$
\mu_{i}=\frac{m_{i}}{M_{i}},
$$

where $m_{i}$ and $M_{i}$ - weight and molecular weight of substance $i$ accordingly.

Values of factor $f$ and $k_{\max }$ for various physico-geographical zones were certain in work [8]. For a subzone of southern taiga in which are considered water-collecting area: $f=2$, and $k_{\max }=300 \div$ 400 relative tons $/\left(\mathrm{km}^{2} \cdot\right.$ year $)$, or translating in power units $k_{\max }=9,79 \cdot 10^{7} \mathrm{~kJ} /\left(\mathrm{km}^{2} \cdot\right.$ year $)$.

The results of definition of chemical load on researched water-collecting area are given in table 2 .

Table 2

\section{Results of environmental load definition with help of chemical exergy}

\begin{tabular}{|c|c|c|}
\hline $\begin{array}{c}\text { Number } \\
\text { of water- } \\
\text { producing } \\
\text { area }\end{array}$ & $\begin{array}{c}\text { Environmental } \\
\text { load, } \\
\mathrm{kJ} /\left(\mathrm{km}^{2} \cdot \text { year }\right)\end{array}$ & $\begin{array}{c}\text { Conclusions about current condition of water-producing area and } \\
\text { ways of its development }\end{array}$ \\
\hline 1 & $6,08 \cdot 10^{6}$ & $\begin{array}{l}\text { Technogenic load is not significant. Ecological situation in } \\
\text { water-producing area is propitious. Any economical activity is } \\
\text { permissible if a standard of discharge is observed. }\end{array}$ \\
\hline 2 & $1,12 \cdot 10^{7}$ & $\begin{array}{l}\text { Technogenic load tends to critical one. Ecological situation in } \\
\text { water-producing area is satisfactory. The increase of technogenic } \\
\text { load is not expedient (the increase of load in result of new objects } \\
\text { building should link with nature-conservancy measures, which } \\
\text { reducing total discharge). }\end{array}$ \\
\hline 3 & $1,83 \cdot 10^{8}$ & $\begin{array}{l}\text { Technogenic load is exceeds maximum permissible standard. } \\
\text { Ecological situation in water-producing area is unsatisfactory. It } \\
\text { is necessary to take measures for reducing discharge }\end{array}$ \\
\hline
\end{tabular}

It is visible from the given example, that we have the necessary information about both technical object and environment using exergy concept. We can expect chemical load, to define the current condition and variants of the territory development.

The further development of the method offered involves the influences of chemical and thermal fields in the GTS and it is being under consideration. 


\section{LIST OF REFERENCES}

1. Yantovskii E. I. (1988). Flows of energy and exergy. Science, Moscow.

2. Wall G., Yantovskii E., Lindquist L. And Tryggstad J. A zero emission combustion power plant for enhanced oil recovery. Energye, Vol. 20, No. 8, pp. 823-828.

DO1 : https://doi.org/10.1016/0360-5442(95)00052-1

3. Gong M. (1999). On exergy as an ecological indicator. M. Sc. thesis, Department of Physical Resource Theory, Goteborg University.

4. Stepanov V. S. (1990). Chemical energy and exergy of substances. Science, Novosibirsk.

5. Frumin G. T. (1993). Thermodynamic estimation of influence of pollutant substances for water ecosystems. Water Resources, 20(6), pp. 726-729.

6. Vorobyev O. G., Zotov L. L., Shishevilov D. V. and Shlyakhov V. A. (1997). Ecological estimation of industrial production life-cycle. Ecological Chemistry, 6(3), pp. 196-203.

7. Vorobyev O. G., Shamshin A. V. and Muzalevskiy A. A. (1998) Opportunities of application of the exergy method of analysis of interaction between industrial object and environment. Ecological Chemistry, 7(2), pp. 110-115.

8. Jorgensen S. and Mejer H. (1981). Application of exergy in ecological models. Liege: CEBEDOC, pp. 587-590.

9. Romanov M. V. (1997). Ecological norm of antropogenic loading for reservoir of small rivers. Ph. D. thesis, Department of hydrotechnics, St. Petersburg State Technical University.

10. Pevzner L. (1977). Fundamentals of bioenergetics. Peace, Moscow.

11. Alekseev G. N. (1983). Energoentropics. Knowledge, Moscow.

12. Zaugolynikov S. D., Kochanov M. M., Loyt A. O. and Stavchanskiy I. I. (1978). Express methods of definition of chemical substances toxic and danger. Medicine, Leningrad.

13. Golubev A. A., Lublina E. I. and others (1973). Quantitative toxicology. Medicine, Leningrad. 